\title{
Exploration and Practice on the Student Status Management in Local University under the Background of Managing the University by Law
}

\author{
Guangya Zhang ${ }^{1,}$, Lingli Fan ${ }^{2, b}$ \\ ${ }^{1}$ Dean's office, Guangdong Ocean University, Zhanjiang 524088, China; \\ ${ }^{2}$ School of ocean and meteorology, Guangdong Ocean University, Zhanjiang 524088, China. \\ azhangguangya@126.com, ${ }^{\text {b }}$ fanlingli@126.com
}

Keywords: Managing the University by Law; the Student Status Management; Governance; Creation and Innovation of Education; Complete Credit System

\begin{abstract}
The new situation of university students' management under the background of comprehensive managing the university by law is analyzed. The importance of student status management in university is emphasized. Many aspects of the student status management in Guangdong Ocean University are summed up, including the high attention of the leaders, teachers and students and other stakeholders involved in, comprehensive governance, the implementation of "governing by law", the innovative student management system and promoting the quality of personnel training etc.; these works have a good reference for the related universities. Look ahead at the problem of students which had undertaken by the social, but retained their status as a student. The exploration and research of the early warning mechanism in the age of big data are looking ahead too.
\end{abstract}

\section{Introduction (the current situation of university students' status management)}

\subsection{The popularization of higher education in China.}

The outstanding performance of the student status management is that the actual teaching resources and management of university can't meet the needs of the individual learning of the students. On the one hand, the higher education popularization, the increase in the number of students and the expansion of the university scale has brought a surge to the regular student status management workload, intensity and difficulty. On the other hand, the popularization of higher education has brought about the reform of the contents, methods of students' status management.

\subsection{Managing the university by law in the round.}

With the continuous improvement of the national legal system, the awakening and strengthening of public awareness of rights, changes of the legal environment in the university, the increase of student safeguarding rights according to law, put forward new requirements on student management work.

\subsection{From management to governance.}

Students in universities do not have enough right to say. University is a typical stakeholder organization. Modern university system requires the internal teaching management of universities, according to the governance ability, responsibility and willingness of the stakeholders in university, to create corresponding mechanism and platform for all stakeholders, to make the proper place and duty in the university governance structure for them, to achieve "common control" [1].

\subsection{Creation and innovation of education.}

"The general office of the state council on deepening the reform of creative education in universities implementation opinion” (2015, No. 36) requirements: reforming of teaching and student status management, to provide institutional support and practical support for the students to carry out innovation and entrepreneurship activities.

\subsection{Complete credit system.}

The views on the implementation of the credit system management in universities by Department of Education of Guangdong” call for the reform of personnel training mode, the implementation of flexible educational system, establishment of mutual recognition of credits system, to meet the new requirements of students' autonomous learning. 


\subsection{Internationalization.}

With the deepening of economic globalization, the international competition of higher education is becoming fierce. Dealing with actively and effectively the challenges of education internationalization has become a major issue concerning the reform and development of higher education in China. Local student status management system does not apply to the "foreign monk".

\subsection{Lifelong learning.}

The national medium and long term education reform and development plan (2010-2020) requires "establishing the concept of lifelong learning". The lifelong learning of higher education is an important driving force in the construction of learning society.

\subsection{Military service.}

The large scale of university students' military service is benefit for the army, after the higher education has entered the stage of mass education from the elite education stage, but after leaving the army and going back to school, the students will face an unknown situation, such as class, professional changes, and so on.

\subsection{Internet and big data.}

"The Ministry of education on strengthening the application and management of the construction of online open courses in universities" has proposed that "to promote innovation of the credit identification of online open courses and credit management system”.

Micro channel has a strong attraction for students, how to play the role of micro channel in university governance, is a subject worthy of study.

In the era of big data, student status management is facing many problems in the process of dealing with data, large amount of business, work complicated and varied, etc.

\subsection{Learning characteristics of new generation.}

Growing up with the Internet, post 90s like to live in their own way, are not restricted by all kinds of regulations, say what they like, just do it, known for "new human” [2], they are always online, they are also known for reading screen generation, the mobile generation. They are willing to learn new things, but keep their attention time is short. They like concise, clear, accurate, refined information and inclined debris of learning content. They reject teaching from the chapters, and pay more attention to the teaching which takes problems as the core. They like the teaching form of interaction between teachers and students, hope to be respected, to discuss with the teachers on the equal, and express their opinions independently. They like to study in a team, not love listening to a long and minute statement and not love difficult learning.

How to adapt to the new situation, to meet the new needs of the society, to solve the new problems encountered in running schools, has become a major challenge to face for student status management.

\section{The important significance of the work of student status management in universities}

2.1 Student status management system reform is not only the basis for the exploration and innovation of university personnel training mode, but also the "bottleneck".

On the one hand, because it runs through the whole process of students' learning, and it is the truest reflection of the content, way and results of personnel training. On the other hand, if the management system restricts the reform of education, restricts the development needs of students, and often becomes the "bottleneck" of the reform of talent training mode.

\subsection{Student status management system reform is one of the important contents of higher education reform and innovation.}

It involves all aspects of the reform of personnel training mode, such as international education, domestic universities collaborative training, education information, industry-university-researchproducing, credit system and other reforms. It involves all aspects of the teaching reform of the course, including classroom teaching methods; renew the teaching contents, academic evaluation system, practice teaching content reform. It involves all aspects of university governance, such as information management, teaching according to law, teaching management. It involves all aspects of student 
individual training, such as autonomous learning ability, practical ability, application ability, innovation and entrepreneurial ability and social adaptability. These are the important content of the innovation of reform in higher education[3].

\subsection{Student status management system reform has function of guiding and encouraging on the growth of students, which get full development of rich individual character.}

Through reform, with a variety of reward and punishment measures, teachers can guide students according to their own interests and personality, to choose their own learning methods, to finish the various learning tasks effectively.

Student status governance involves all the contents of students' learning activities during the period of university. It is the main starting point for the implementation of personnel training, through the whole process for the students from admission to graduate. Universities can make full use of it, to adjust and monitor the relevant aspects of personnel training effectively, can create a suitable system environment for talent, can classify training personnel in order to adapt to the needs of industrial development, so as to achieve the goal of everyone.

\section{The exploration and practice of the student status management in Guangdong Ocean University}

\subsection{Leadership attaches great importance to it.}

The allocation of special funds protects the improvement of the student status management level effectively. Academic department, student department and colleges do cooperative cooperation, set up a two level management responsibility system.

\subsection{Multi participation, comprehensive management.}

Encouraging and guiding the stakeholders of governance--students to participate actively, they are both managers and managers, can enhance students' self-control and restraint ability effectively, and the university can change from passive management to active service. Seeking the views of students by the school opens, seminars and other forms, in order to ensure the democracy of the system establishment. Holding training communication meetings related to the student status management regularly; carrying out various forms of education activities for all students to help them clear school management system. Improve school management workflow, to be open, fair, impartial, and safeguarding the seriousness of the policy and the legitimate rights and interests in students. Update the concept of management, integrating services and management, the management and education into one. The establishment of "students' academic support center" provides more guidance and services for students' personalized learning.

\subsection{The implementation of "Managing the University by Law".}

Provide protection for the status management. Correctly treat the legal status of the university and students, respecting the main position for students in education management, paying attention to the participation of the students. Let the "due process" to penetrate into the whole process of management, to ensure all work running in accordance with law from beginning to end.

\subsection{Innovating status management system, deepening the teaching reform, to promote the} quality of personnel training.

\subsubsection{The reform of credit system}

According to the objective law of the development of talent, implementing of flexible educational system, course-selecting system, carry out reform from many aspects, such as enrollment, tuition collection, etc. Constructing a new teaching management system and teaching organization mode, to achieve the optimal allocation of teaching resources, and fully mobilize the enthusiasm and initiative of teaching and learning[4].

\subsubsection{The innovation of talent training mode}

With "double hundred projects" as the starting point, to implement top-notch innovative talents training, the "double hundred projects" is refers to the university from the annual enrollment of undergraduate selection about two hundred outstanding students, divided into academic and 
management class to focus on training plan (hereinafter referred to as the "double hundred" project).Perfecting double degree, minor study programs, to implement the training mode of compound talents. Construct the training mode of applied talents with different characteristics and establish exchanges and training mechanisms for students to the domestic and foreign university[5].

\subsubsection{Strengthening the innovation and entrepreneurship education}

Introducing "The opinions on strengthening the work of innovation and entrepreneurship education of undergraduate students in Guangdong Ocean University", to further strengthen the innovation and entrepreneurship education, from revising the talent training program, promoting depth integration of innovation and entrepreneurship education and professional education, reforming teaching and management system and so on.

\subsubsection{Optimization of talent training program}

Further reduce the class hours, to leave space for the students' autonomous learning. According to the professional training target that corresponds with the talent training mode, optimize the training plan with classified type. For example, for the purpose of the application of personnel training, highlighting the practice of teaching expands the proportion of elective courses, application courses, practical courses, adding the characteristics supplementary courses which relate with qualification examination and employment.

\subsubsection{To create "six classroom" linkage system}

Constructing and implementing of the "six classroom" system, strengthening teaching and interaction in full range of the whole process. The first class focuses on encouraging the innovation of theory teaching, strengthening the heuristic and interactive teaching. The second classroom is the practical teaching, which supports for the reform of the experimental class, including the establishment of autonomous learning, special training, summary exchanges seminars and other aspects of the combination of learning and thinking. Third classroom activities focus on the development of campus culture and innovation practice, strengthen the quality of students. Fourth classroom bases practice teaching base, focusing on the development of professional practice and social practice. Fifth classroom support implementation of overseas training programs for all units and professional support students communicate in a well-known university. Sixth classroom focus to build high-quality network teaching resources platform to promote MOOC and hybrid teaching reform, improve students' autonomous learning ability. The linkage of "Six classroom” creates a full range of talent environment.

\subsubsection{Improvement of classroom teaching methods}

Under the background of the current digital campus, in view of the characteristics of the new generation, being willing to learn new things, keeping the attention time is short, the learning content tend to fragmentation, not loving a long and minute statement etc.. Developing and constructing of micro class, MOOC, by using “own equipment”, such as intelligent mobile phone etc., to guide students to make full use of all kinds of moments of fragmentation to learn. To apply the "flipped classroom" innovation teaching mode, put the "classroom information feedback system" into the classroom teaching, by using of micro channel and other new media. Improve the interaction and participation of the modern classroom teaching, improving the attractiveness and effectiveness of the classroom, to adapt to the lifestyle, personality, learning characteristics of the new generation.

\subsubsection{International cooperation}

Printing and distributing "The interim measures for the status management of exchange students in Guangdong Ocean University”, “Open education development plan”, “International exchange and cooperation project of talent cultivation", to explore and establish open, pluralistic, win-win, distinctive international exchanges and cooperation mode in higher education gradually.

\subsubsection{Specification for changing majors, transferring education}

Introducing "The detailed rules for the implementation of undergraduate students transfer education in Guangdong Ocean University”, “The approach for the implementation of undergraduate students change majors in Guangdong Ocean University”, to regulate the transfer, change majors 
students, to safeguard the fairness and justice of education and the legal rights of students, and fully mobilize the enthusiasm and initiative of learning.

\subsubsection{Security of information management}

Implement precision management, updating school data timely, to do a good job in the new student enrollment electronic registration, school year electronic registration, academic electronic registration, etc. Enhance students' consciousness of inspecting status, to maintain their own rights, to improve the accuracy of status data.

\subsubsection{The reform of students' academic evaluation}

Mastering of students' learning situation through academic evaluation, to discover and develop the potential of students, understand the needs of the development of students. Helping students to know themselves, build self-confidence, and promote the development of students in the original level. Adjust the proportion of the usual open test and final examination scores, pay attention to the students' learning attitude, learning methods and learning ability.

\section{The further thinking of doing a good job in status management}

\subsection{About the problem of students which had undertaken by the social, but retained their status as a student still.}

They flow to the community and become the "quasi-finished", and "semi-finished products" of the high quality labor force for the society. Their social rights should be how to define and protect how to continue their social security, health care, household registration, etc., all should also have the corresponding policy adjustments.

\subsection{The exploration and research of the early warning mechanism in the era of big data.}

In the background of the era of big data, how to change the current situation of the post warning, hysteresis treatment, to establish a dynamic early warning education mechanism, to carry out dynamic monitor on the student's bad idea and behavior[6]. Doing early warning and guidance to students who have abnormal status, prior warning education, track management of hindsight, to prevent students from can't completing their studies or other undesirable results.

\section{Acknowledgment}

Fund Projects: Higher education teaching reform project of Education Department of Guangdong Province in 2015: Research and practice on the innovation of credit system teaching management system based on Internet thinking.

\section{References}

[1]. Gong Yizu: “Governance Structure of University: The Cornerstone of Modern University System,” Educational Research, Vol. 353, p.22-26, June 2009. (In Chinese)

[2]. Li Mang. "The students' learning guidance and teaching mode innovation in the new era [EB/OL] ,” http://gdou.enetedu.com/SchoolCourse/Process?course_id=611,unpublished. (In Chinese)

[3]. Lin Jing, Tao Aiping, "College Enrollment Management System Construction Research,” Zhejiang University Press. (In Chinese)

[4]. Xiao Yi, Liu Min, Zong Lian-song, Guo Li, “Thoughts on the Status Management Reform of Higher Education under the Credit System,” Education and Teaching Research, vol. 25, pp. 64-66, February 2011. (In Chinese)

[5]. L.L, Fan and G.Y. Zhang: "Exploration and practice of the application of multidisciplinary Ocean University of atmospheric science professional training talents,” Ocean Development and Management, Vol. 28 p.47-50. November 2011. (In Chinese) 
[6]. Han Fengxia, "The exploration and research of the early warning mechanism in the era of big data, “The Chinese Journal of ICT in Education, No.19, 46-49, 2015. (In Chinese) 